\title{
Sistem Monitoring Tingkat Kekeruhan Air dan Pemberi Pakan Otomatis pada Kolam Budidaya Ikan Koi Berbasis NodeMCU
}

\author{
I Gede Hery Putrawan ${ }^{1}$, Pratolo Rahardjo ${ }^{2}$, I Gusti Agung Putu Raka Agung ${ }^{3}$ \\ Submission: 09-10-2019, Accepted:14-10-2019
}

\begin{abstract}
In this study, a prototype system was designed to monitoring the water turbidity levels and also automatically feeding the koi fish in a cultivation pool, which the main purpose is to improving the quality of koi fish cultivation. The prototype used a plastic box measuring $50 \mathrm{~cm} \times 35 \mathrm{~cm} \times 30 \mathrm{~cm}$, so the volume of water obtained is 52.5 liters. The water turbidity monitoring system works by reading the turbidity value of the water using a turbidity sensor TSD-10, then the data sensor will be processed by the NodeMCU microcontroller. If the water turbidity level is detected high, the system will activate the drainage pump to drain the turbid water. On the other hand, there is a proximity sensor that will measure the height of the water. When the turbid water is drained, the proximity sensor will send a signal to NodeMCU microcontroller and then activate the distribution pump, so that it can distribute clean water from water tank to the pool. Therefore, the water in koi fish cultivation pool will always be clean. Meanwhile, the automatic feeding system work by using a RTC (Real Time Clock) module which is the feeding time will be set on this module. Then, the time output from the RTC module will be processed by the NodeMCU microcontroller to drive the motor servo so the fish lever could be open and closed. When it is time for feeding, according to the program that has been set in RTC module, the fish feed lever will be open for three second and then closed again. Therefore, feeding the fish could be automatically.
\end{abstract}

Intisari - Pada penelitian ini dirancang suatu prototipe sistem untuk dapat memonitoring tingkat kekeruhan air dan pemberi pakan otomatis pada kolam budidaya ikan koi dengan tujuan membantu pembudidaya ikan koi meningkatkan kualitas hasil budidaya mereka. Pada prototipe alat digunakan box plastik berukuran $50 \mathrm{~cm} \times 35 \mathrm{~cm} \times 30 \mathrm{~cm}$, sehingga diperoleh volume air 52.5 liter. Prinsip kerja sistem monitoring tingkat kekeruhan air kolam budidaya koi ini adalah dengan membaca nilai kekeruhan air kolam menggunakan sensor kekeruhan (Turbidity Sensor TSD-10). Pembacaan nilai sensor tersebut akan diproses mikrokontroler NodeMCU kemudian mengaktifkan modul relay pompa drainase untuk menguras air keruh.

${ }^{1}$ Mahasiswa, Teknik Elektro dan Komputer Fakultas Teknik Universitas Udayana, Jln. Kunti II No.36 Seminyak, 80361. INDONESIA (telp:081936252986; e-mail: heryputrawan35@gmail.com).

${ }^{2}$ Dosen, Program Studi Teknik Elektro dan Komputer Fakultas Teknik Universitas Udayana, Jln. Tukad Yeh Panan, Blok XIX No.32, Kediri, Tabanan, 82123 INDONESIA (telp: 08155770953; e-mail:pratolo@unud.ac.id).

${ }^{3}$ Dosen, Program Studi Teknik Elektro dan Komputer Fakultas Teknik Universitas Udayana, Br. Anggarkasih, Medahan, Blahbatuh Gianyar 80581 INDONESIA (telp:081999898301; e-mail: igapraka@yahoo.co.id).
Di sisi lain terdapat sensor jarak yang akan mengukur ketinggian air kolam. Pada saat air kolam sudah terkuras, maka sensor jarak akan mengirimkan sinyal ke mikrokontroler NodeMCU untuk mengaktifkan modul relay pompa distribusi, sehingga dapat mendistribusikan air bersih dari tangki air menuju kolam. Dengan demikian, air kolam budidaya akan selalu dalam keadaan bersih. Sementara itu, untuk pemberi pakan otomatis bekerja dengan menggunakan modul RTC (Real Time Clock DS1307) dimana waktu pemberian pakan akan disetting pada modul ini. Kemudian, output berupa waktu dari modul RTC akan diproses mikrokontroler NodeMCU yang kemudian mengirimkan sinyal menuju servo sebagai penggerak tuas tempat pakan ikan. Apabila sudah waktunya pemberian pakan sesuai dengan program yang diberikan, maka tuas pakan ikan akan terbuka selama tiga detik dan menutup kembali. Dengan demikian, pemberian pakan dapat dilakukan secara otomatis.

Kata Kunci-IoT, monitoring, kekeruhan, pakan, kolam, ikan koi.

\section{PENDAHULUAN}

Saat ini tidak sedikit masyarakat Indonesia bekerja sebagai pembudidaya ikan. Karena dengan budidaya, selain untuk menyalurkan hobi juga dapat memberikan keuntungan bagi pembudidaya itu sendiri. Salah satu budidaya yang banyak dilakukan oleh masyarakat Indonesia adalah budidaya ikan. Ada banyak jenis ikan yang dibudidayakan di Indonesia, namun yang paling menjanjikan adalah ikan koi karena paling banyak diminati.

Untuk membudidayakan ikan koi tentunya diperlukan beberapa kolam dan kolam-kolam tersebut tentunya harus selalu dirawat dan dijaga kebersihannya untuk menghasilkan ikan koi yang berkualitas. Namun hingga saat ini, masih banyak pembudidaya ikan koi yang membersihkan kolam mereka dengan cara manual. Seperti contohnya menguras air kolam dengan alat seadanya atau mungkin yang terbaru adalah dengan mesin penguras, namun penggunaannya masih dengan cara manual. Hal tersebut tentunya akan mengurangi efisiensi pembudidaya dalam melakukan pembersihan (pengurasan air) pada kolam. Dengan memanfaatkan teknologi, tentunya akan sangat membantu pembudidaya ikan koi di Indonesia dalam melakukan pembersihan khususnya pengurasan air kolam.

Pada penelitian sebelumnya telah dibuat suatu sistem monitoring tingkat kekeruhan air menggunakan sistem minimum ATMega8 dan sensor kekeruhan TSD-10. Alat 
yang dirancang tersebut digunakan untuk memonitoring tingkat kekeruhan air minum dengan tujuan untuk mengetahui apakah air tersebut layak dikonsumsi atau tidak [1].

Sama seperti penelitian tersebut, pada penelitian ini juga menggunakan sensor kekeruhan TSD-10 sebagai pendeteksi tingkat kekeruhan air. Namun perbedaannya terletak pada mikrokontroler yang digunakan dan kegunaan sistem yang dirancang. Pada penelitian ini digunakan mikrokontroler NodeMCU sehingga sistem dapat dikoneksikan dengan internet untuk implementasi IoT (Internet of Things). Kemudian kegunaan sistem pada penelitian ini adalah untuk memonitoring tingkat kekeruhan air pada kolam budidaya ikan koi dan hasil monitoring akan dikirimkan menuju smartphone pemilik kolam dengan menggunakan teknologi IoT (Internet of Things) yang diimplementasikan pada sistem.

\section{TinJAUAn PUSTAKA}

Berikut ini merupakan beberapa tinjauan pustaka yang memiliki keterkaitan dengan sistem yang dibuat.

\section{A. Internet of Things (IoT)}

Internet of Things bisa disebut dengan IoT, adalah suatu pengembangan teknologi yang memanfaatkan konektivitas internet yang selalu terhubung. Internet of Things berpengaruh sangat besar dalam segala bidang karena hampir keseluruhan bidang ilmu pengetahuan dapat diaplikasikan dengan teknologi Internet of Things. Oleh karena itu, Internet of Things disebut "The Next Big Things" di dunia teknologi informasi. Contoh sederhana dari Internet of Things adalah pengguna dapat menyalakan atau mematikan lampu melalui internet dari jarak yang sangat jauh [2].

\section{B. Ikan Koi}

Ikan koi termasuk dalam jenis ikan mas atau Cyprinus carpio dimana ikan jenis ini memiliki ornamen atau corak yang indah dan beraneka ragam sehingga banyak diminati. Koi banyak dipelihara, selain karena digunakan untuk hiasan juga karena hobi dan akhirnya berkembang menjadi budidaya. Selain itu, ikan koi juga dipercaya sebagian orang dapat memberi keberuntungan [3]. Ikan koi memiliki beberapa keistimewaan yang membedakannya dengan ikan hias lainnya, diantaranya:

1. Mudah beradaptasi.

2. Menerima semua jenis makanan (Omnivora).

3. Berumur panjang.

4. Memiliki banyak bervariasi.

5. Ikan yang jinak.

\section{Kolam Budidaya}

Kolam budidaya merupakan suatu lahan yang sengaja digarap oleh manusia dengan tujuan memelihara dan membudidayakan berbagai jenis hewan air seperti ikan dan sebagainya [4]. Berdasarkan pengertian teknis, kolam adalah wilayah perairan yang dibuat dengan ukuran tertentu sehingga dapat dikelola oleh pemilik kolam itu sendiri. Kolam ikan direkomendasikan oleh FAO (Food and Agriculture
Organization of The United Nations) untuk dikembangkan di negara miskin dan berkembang karena mampu meningkatkan pertumbuhan ekonomi.

\section{Sanitasi Kolam Budidaya Ikan}

Sanitasi kolam biasanya dilakukan dengan menjaga kebersihan kolam dan air yang digunakan. Pada umumnya, kolam yang kondisi lingkungannya buruk atau kurang terawat akan lebih mudah ditumbuhi ganggang atau jenis parasit lainnya sehingga dapat menurunkan kualitas hasil budidaya. Oleh sebab itu, agar tidak menjadi sumber penyebaran penyakit atau parasit maka kolam diusahakan agar selalu dalam kondisi bersih terutama kualitas airnya. Karena dari air yang kualitasnya buruk banyak terdapat organisme-organisme yang bersifat parasit dan itu pula yang menyebabkan ganggang dan sebagainya tumbuh dengan cepat pada kolam [5].

\section{E. Kekeruhan Air}

Kekeruhan merupakan suatu kondisi air yang di dalamnya terdapat sedikit atau banyak pertikel-pertikel halus yang kadang tak kasat mata sehingga diperlukan suatu alat dengan efek cahaya untuk mengukur kondisi air baku dengan skala NTU (Nephelometric Turbidity Unit). Kekeruhan pada air terjadi karena tercampurnya air oleh benda atau partikel halus sehingga menyebabkan perbedaan warna pada air menjadi keruh atau tidak jernih [6]. Kekeruhan air semakin meningkat berbanding lurus dengan banyaknya partikel yang terkandung pada air itu sendiri.



Air dikatakan memiliki kualitas baik apabila air tersebut jernih (mengandung sedikit partikel penyebab kekeruhan). Adapun batas maksimal kekeruhan air untuk kolam budidaya ikan adalah 400 NTU [7]. Kekeruhan air dapat ditimbulkan oleh partikel-partikel kecil misalnya debu dan partikel kecil lainnya. Dimana partikel-partikel ini apabila dalam jumlah banyak dapat menghalangi masuknya sinar matahari sehingga menyebabkan pertumbuhan ganggang, parasit dan bibit penyakit lainnya pada kolam.

\section{F. ESP8266 NodeMCU}

ESP8266 NodeMCU merupakan suatu platform IoT (Internet of Things) yang bersifat opensource. Terdiri dari perangkat keras berupa System on Chip ESP8266 buatan Espressif System, juga firmware yang digunakan yang menggunakan Bahasa pemrograman scripting LUA. Istilah 
NodeMCU secara default sebenarnya mengacu pada firmware yang digunakan, dimana NodeMCU meupakan modul pengembangan dari modul platform IoT keluarga ESP8266.

Modul ini sama halnya dengan Arduino yang digunakan sebagai mikrokontroler, namun yang membuatnya berbeda yaitu dikhusukan untuk "Connected to Internet" [8].



Gambar 2 : NodeMCU Versi 1.0 (unofficial board)

\section{G. Sensor Kekeruhan Air TSD-10}

Sensor kekeruhan air TSD-10 merupakan salah satu alat yang dapat digunakan sebagai pengukur tingkat kekeruhan air. Semakin banyak partikel dalam air maka tingkat kekeruhan air juga semakin tinggi. Pada sensor kekeruhan, semakin tinggi tingkat kekeruhan air akan diikuti dengan perubahan tegangan output sensor [9].



Gambar 3 :Sensor Kekeruhan Air TSD-10

\section{H. Sensor Jarak HC-SR04}

Sensor jarak merupakan suatu sensor yang digunakan sebagai pengukur jarak. Sensor ini juga disebut dengan sensor ultrasonik dikarenakan pada sensor ini digunakan gelombang ultrasonik sebagai pengukur jarak. Prinsip kerja dari sensor ini adalah dengan memancarkan gelombang ultrasonik menuju benda yang akan diukur jaraknya, kemudian benda tersebut akan memantulkan kembali gelombang ultrasonik menuju sensor maka dengan demikian dapat diketahui jarak benda [10].



I. RTC (Real Time Clock)

I Gede Hery Putrawan: Sistem Monitoring Tingkat Kekeruhan...
RTC atau Real Time Clock merupakan modul jam elektronik yang berupa chip, modul ini biasanya digunakan untuk menghitung waktu dari detik hingga tahun. Pada modul RTC terdapat sebuah baterai $3.3 \mathrm{~V}$ sebagai sumber tegangan sehingga RTC masih tetap bisa menghitung waktu walaupun sistem lainnya tidak aktif. Modul RTC ini bekerja secara realtime dimana setelah proses hitung waktu dilakukan, output datanya langsung disimpan [11].



Gambar 5 : Modul RTC (Real Time Clock) DS1307

\section{J. Servo}

Servo merupakan sebuah motor DC yang memiliki sistem umpan balik tertutup, dimana pada servo terdapat rangkaian kontrol yang akan menginformasikan posisi rotor. Servo terdiri dari sebuah motor DC, serangkaian gear, potensiometer dan rangkaian kontrol. Potensiometer berfungsi untuk menentukan batas sudut dari putaran servo. Sedangkan sudut dari sumbu motor servo ditentukan dengan lebar pulsa pada pin sinyal servo [12].



Gambar 6 : Motor Servo

\section{K. Modul Relay}

Relay merupakan suatu komponen elektronika yang dapat difungsikan sebagai saklar. Relay juga disebut saklar elektrik dikrenakan saklar ini digerakkan secara mekanis dengan energi listrik. Terdapat dua bagian utama pada relay, yaitu bagian elektromagnet dan mekanikal (kontak saklar). Komponen elektronika ini menggunakan prinsip elektromagnetik untuk menggerakkan kontak sehingga dapat digunakan sebagai penghantar arus listrik bertegangan tinggi [13].



Gambar 7 : Bentuk Fisik Modul Relay

p-ISSN:1693 - 2951; e-ISSN: 2503-2372 


\section{Arduino IDE}

Untuk dapat digunakan tentunya board mikrokontroler perlu diberi program. Pada sistem disini digunakan board NodeMCU sehingga untuk dapat digunakan perlu diberikan program. Namun sebelumnya perlu dibuatkan sketch pada aplikasi IDE (Integrated Development Environment) dari Arduino yang ditunjukkan pada gambar 8 .

Kemudian setelah sketch atau program selesai dibuat, maka selanjutnya tinggal mengupload sketch tersebut menuju mikrokontroler sehingga mikrokontroler dapat digunakan sesuai dengan alat yang akan dibuat [14].



\section{Blynk}

Blynk merupakan salah satu aplikasi mobile yang dapat digunakan untuk mengontrol modul-modul mikrokontroler seperti salah satu contohnya ESP8266 NodeMCU melalui internet tanpa terikat pada board atau modul tertentu. Aplikasi ini dapat digunakan sebagai wadah kreatifitas dalam membuat antarmuka grafis pada suatu project hanya dengan menggunakan widget yang sudah disediakan. Dengan aplikasi ini, pengguna dapat membuat suatu project Internet of Things sederhana [15].



Gambar 9 : Contoh Penggunaan Aplikasi Blynk

\section{HASIL DAN PEMBAHASAN}

Hasil dan pembahasan pada sistem monitoring tingkat kekeruhan dan pemberi pakan otomatis pada kolam budidaya ikan koi berbasis NodeMCU adalah sebagai berikut.

\section{A. Perancangan Hardware (Perangkat Keras)}

Perancangan hardware pada sistem monitoring tingkat kekeruhan air dan pemberi pakan otomatis pada kolam budidaya ikan koi menggunakan program Fritzing 0.9.3 yang ditunjukkan pada gambar 10 dan 11 .

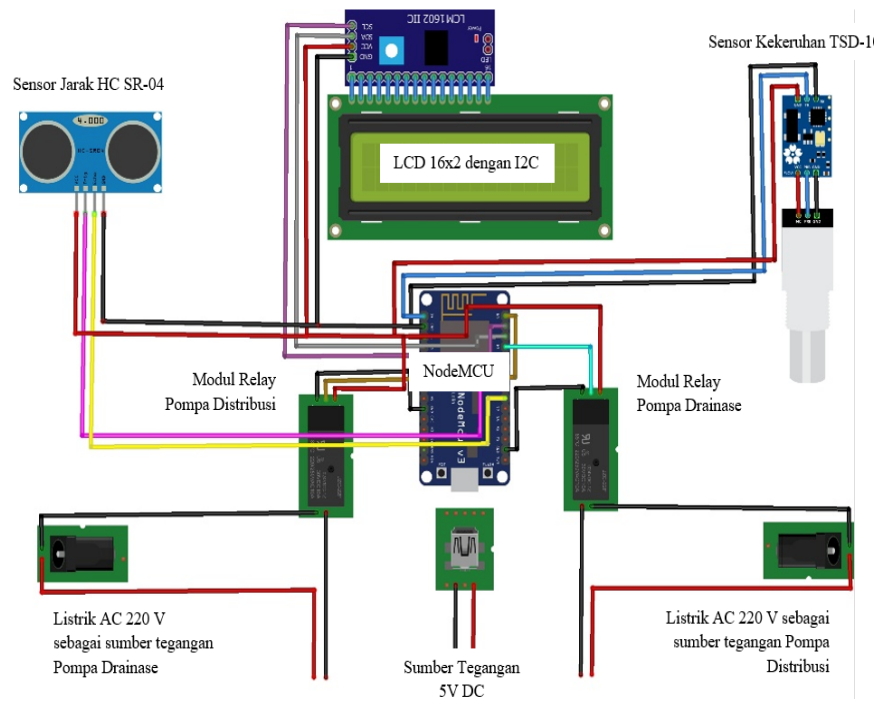

Gambar 10: Rangkaian Sistem Monitoring Tingkat Kekeruhan Air



Gambar 11: Rangkaian Sistem Pemberi Pakan Ikan Otomatis

Kemudian, realisasi rancangan hardware atau prototype sistem ditunjukkan pada gambar $12 \mathrm{a}, \mathrm{b}$ dan $\mathrm{c}$.






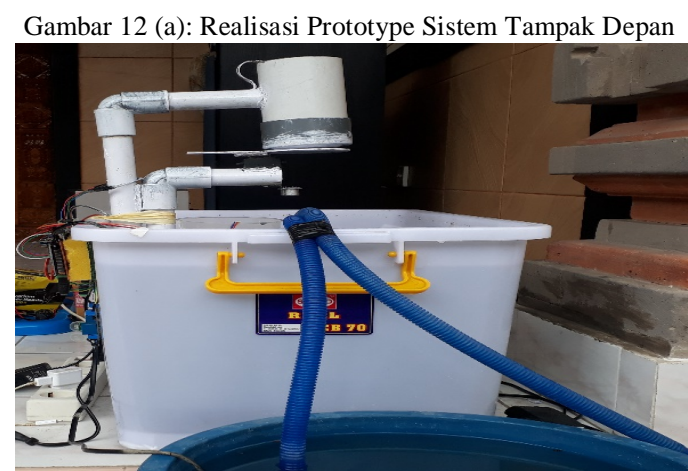

Gambar 12 (b): Realisasi Prototype Sistem Tampak Samping

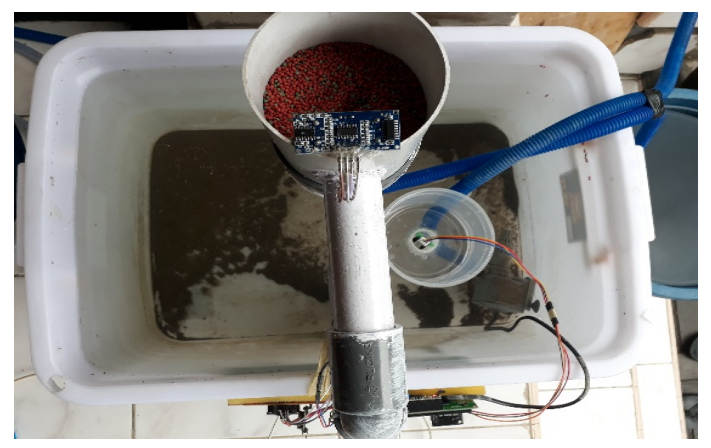

Gambar 12 (c): Realisasi Prototype Sistem Tampak Atas

\section{B. Perancangan Software (Perangkat Lunak)}

Perancangan software (perangkat lunak) pada sistem monitoring tingkat kekeruhan air kolam dan pemberi pakan ikan otomatis ini menggunakan software Arduino IDE 1.8.10. Adapun diagram alir pada sistem monitoring tingkat kekeruhan air dan pemberi pakan ikan otomatis sesuai dengan program yang diberikan dapat dilihat pada gambar 13 dan 14 .

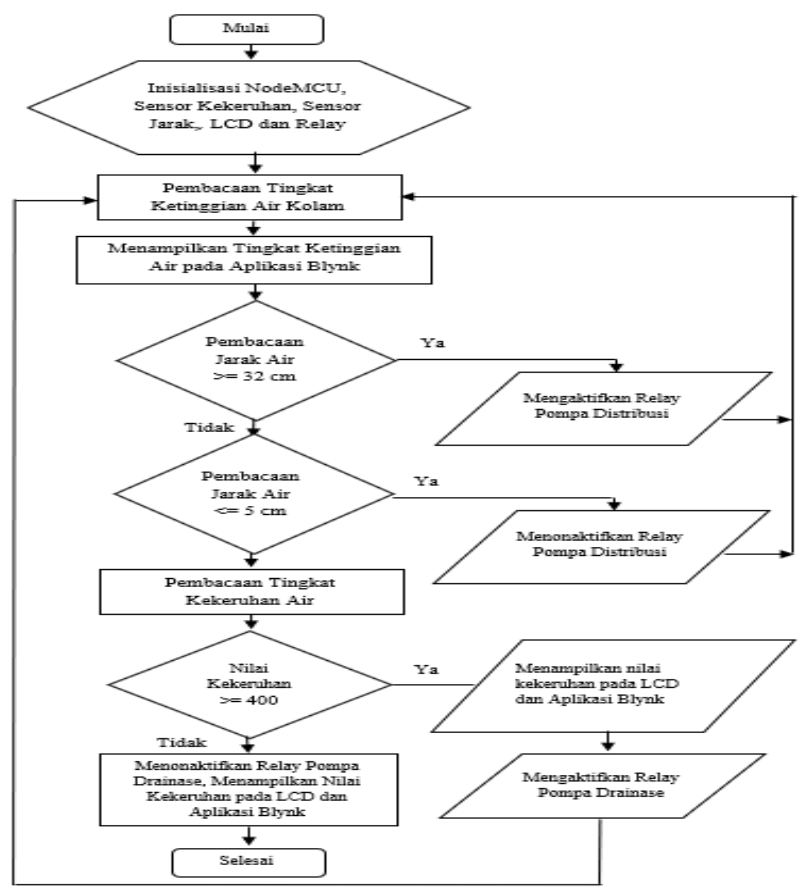

Gambar 13: Diagram Alir Sistem Monitoring Tingkat Kekeruhan Air

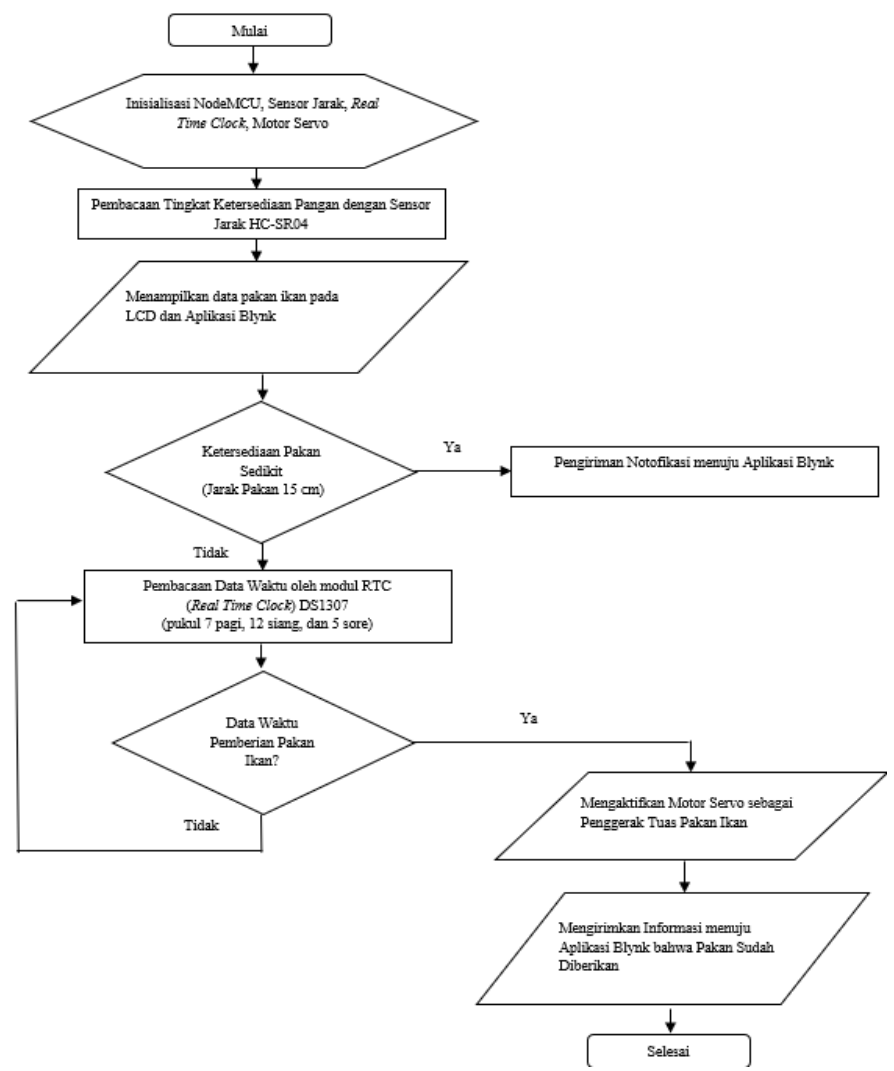

Gambar 14: Diagram Alir Sistem Pemberi Pakan Ikan Otomatis

\section{Pengujian dan Pembahasan Rangkaian Power Supply}

Sumber energi yang digunakan dalam mengoperasikan perangkat ini adalah Adaptor 5 Volt 1 Ampere untuk masingmasing sistem yaitu sistem monitoring kekeruhan air kolam dan sistem pemberi pakan ikan otomatis. Pemilihan adaptor 5 Volt 1 Ampere karena sudah dapat mencakup semua beban yang digunakan yaitu, pada sistem monitoring kekeruhan air menggunakan mikrokontroler NodeMCU, sensor kekeruhan TSD-10, sensor jarak HC-SR04, modul relay dan LCD sementara pada sistem pemberi pakan ikan otomatis menggunakan mikrokontroler NodeMCU, modul Real Time Clock, sensor jarak HC-SR04 dan motor servo. Sementara untuk sumber tegangan servo MG996R menggunakan adaptor 12 Volt 1 Ampere. Hasil pengujian rangkaian power supply ditunjukkan pada gambar 15 a dan $\mathrm{b}$.

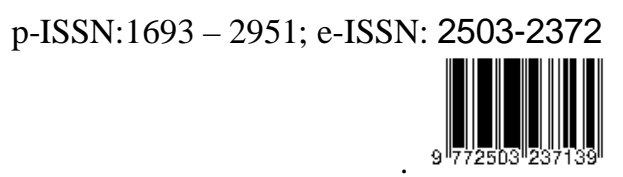




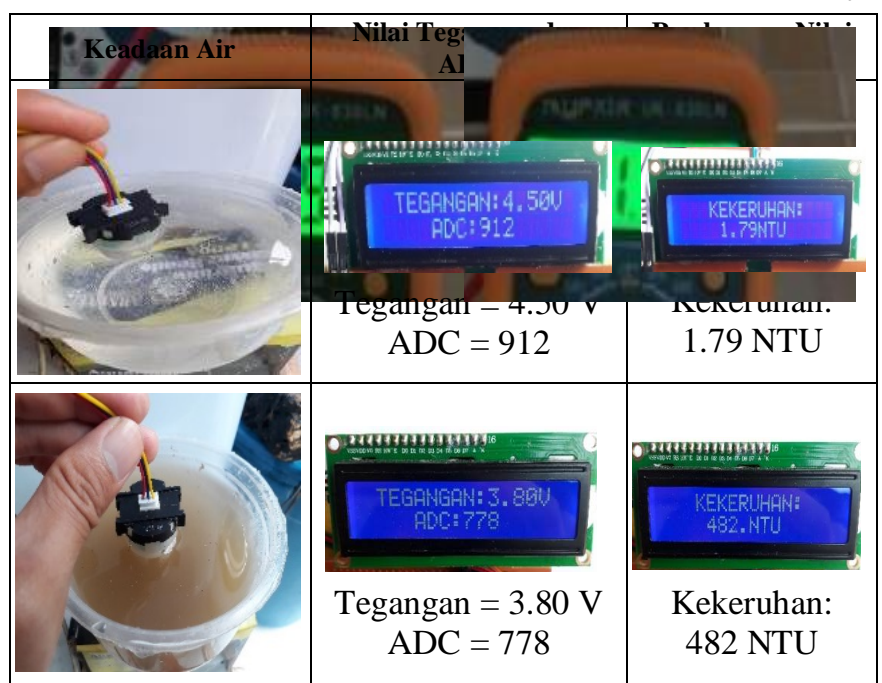

(a)

(b)

Gambar 15 : (a) Hasil Pengujian Tegangan Output dari Adaptor 5 V DC dan (b) Hasil Pengujian Tegangan Output dari Adaptor 12 V DC

D. Pengujian LCD 16x2 pada Sistem Monitoring Tingkat Kekeruhan Air

Tampilan Display sistem monitoring tingkat kekeruhan air kolam budidaya ikan koi ini menggunakan LCD 16x2 dan I2C. I2C digunakan untuk komunikasi serial dua arah yang didisain khusus untuk mengirim maupun menerima data. Sistem I2C terdiri dari saluran SCL (Serial Clock) dan SDA (Serial Data) yang membawa informasi data antara I2C dengan pengontrolnya. Dengan menggunakan modul I2C dapat menghemat penggunaan pin mikrokontroler NodeMCU dibandingkan menggunakan saluran parallel. Skema pengujian rangkaian LCD pada sistem monitoring tingkat kekeruhan air kolam budidaya ikan koi ditunjukkan pada gambar 16.

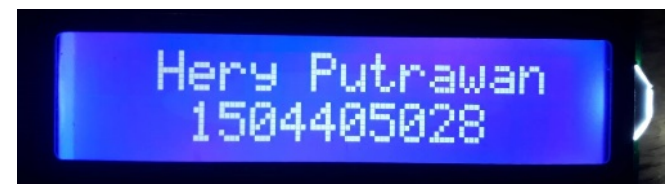

Gambar 16 : Hasil Pengujian LCD 16x2 dengan I2C

\section{E. Pengujian Sensor Kekeruhan Air TSD-10}

Pada penelitian ini, digunakan sensor kekeruhan (turbidity sensor) tipe TSD-10 untuk membaca nilai tingkat kekeruhan air. Sensor ini memiliki sebuah penguat (amplifier) menghubungkan sensor dengan mikrokontroler Node-MCU. Dari 8 pin pada penguat, 2 digunakan sebagai sumber yaitu $\mathrm{VCC}+5 \mathrm{~V}$ dan GND, sebuah pin sinyal analog kemudian 3 pin sisanya akan terhubung ke modul sensor. Pada sensor kekeruhan, semakin tinggi tingkat kekeruhan air akan diikuti dengan perubahan dari tegangan output sensor yang semakin kecil dan sebaliknya. Hasil pengujian sensor kekeruhan TSD10 ditunjukkan pada tabel 1.

TABEL 1

PENGUJIAN SENSOR KEKERUHAN TSD-10

\section{F. Pengujian Sensor Jarak HC-SR04}

Pada sistem ini juga dilengkapi dengan dua buah sensor jarak HC-SR04. Sebuah sensor untuk memantau ketinggian air kolam dimana apabila air kolam keruh dan sudah terkuras maka sensor jarak HC-SR04 ini akan mendeteksi bahwa air kolam dangkal (jarak sensor menuju air kolam $<=32 \mathrm{~cm}$ ). Hal ini menyebabkan mikrokontroler mengaktifkan relay pompa distribusi untuk menyalurkan air bersih menuju kolam. Kemudian sebuah sensor lagi digunakan untuk memantau ketersediaan pakan ikan dengan mengukur tinggi rendahnya pakan pada wadah. Apabila pakan ikan yang tersisa sedikit (jarak sensor menuju pakan $<=13 \mathrm{~cm}$ ) maka sistem akan memberikan notifikasi kepada pemilik kolam bahwa pakan ikan akan habis dan perlu diisi kembali. Hasil pengujian sensor jarak HC-SR04 ditunjukkan pada tabel 2 dan 3.

TABEL 2

HASIL PENGUJIAN SENSOR JARAK HC-SR04 PADA PENGUKURAN KETINGGIAN AIR

\begin{tabular}{|c|c|}
\hline $\begin{array}{c}\text { Pengukuran } \\
\text { Secara Manual }\end{array}$ & $\begin{array}{c}\text { Tampilan Hasil } \\
\text { Pengukuran pada } \\
\text { Aplikasi Blynk } \\
\text { (Chart Biru Tua) }\end{array}$ \\
\hline & $\begin{array}{c}\text { Thtrsivi in } \\
\text { Ketinggian air: } \\
\text { Tinggi Wadah - Hasil } \\
\text { Pengukuran } \\
35 \mathrm{~cm}-10 \mathrm{~cm}=25 \mathrm{~cm}\end{array}$ \\
\hline
\end{tabular}




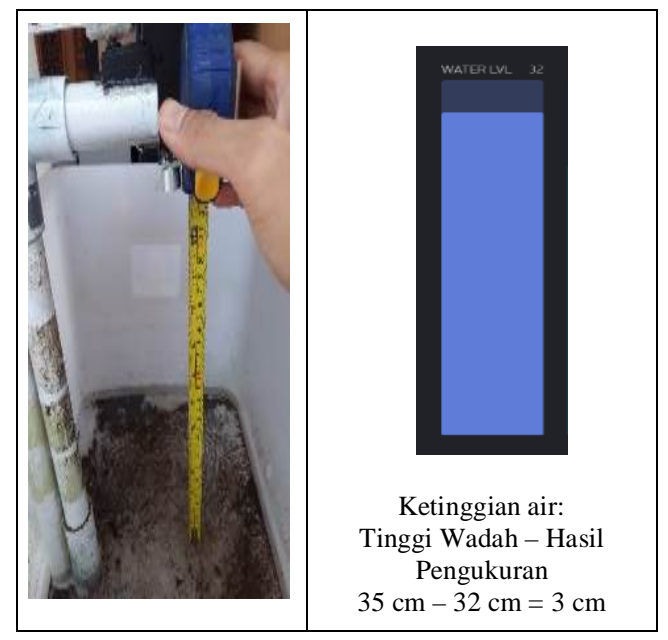

TABEL 3

PENGUJIAN SENSOR JARAK HC-SR04 PADA PENGUKURAN KETERSEDIAAN PAKAN IKAN

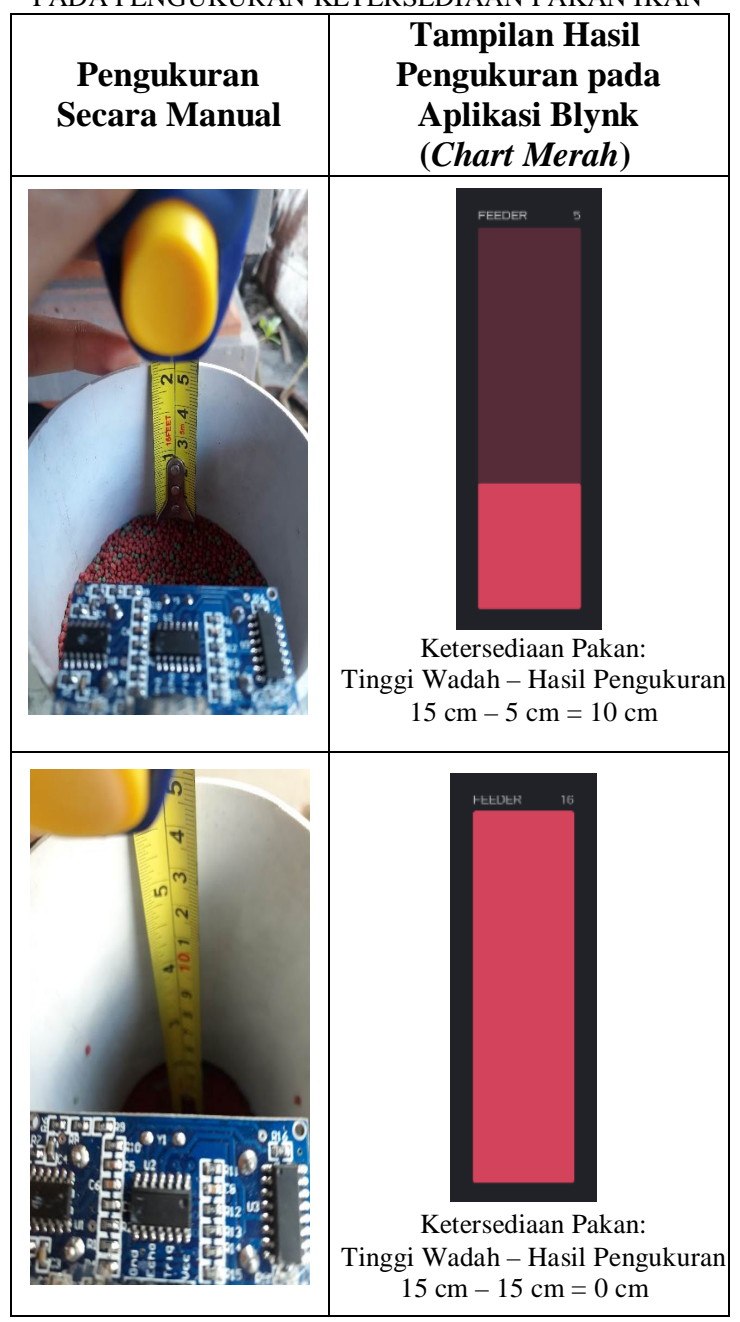

I Gede Hery Putrawan: Sistem Monitoring Tingkat Kekeruhan...
Hasil pengukuran merupakan jarak sensor dengan benda (air dan pakan ikan) yang diukur sehingga tampilan chart berbanding terbalik. Apabila jarak benda jauh, maka tampilan chart tinggi dan sebaliknya apabila jarak benda dekat, maka tampilan chart rendah. Pada pegukuran jarak air dangkal, digunakan jarak maksimal $32 \mathrm{~cm}$ dikarenakan mengikuti ukuran wadah (box plastik) yang digunakan pada prototype dimana saat air pada wadah (box plastik) sudah terkuras diperoleh jarak $32 \mathrm{~cm}$. Sementara itu, pada pengukuran ketersediaan pakan pada wadah yang memiliki tinggi $20 \mathrm{~cm}$, digunakan jarak maksimal $15 \mathrm{~cm}$ pada keadaan pakan ikan habis dikarenakan pada jarak tersebut pakan ikan sudah sedikit atau akan habis. Berdasarkan pengujian yang telah dilakukan, hasil pengukuran secara manual dan hasil pengukuran pada aplikasi Blynk tidak jauh berbeda sehingga dapat dikatakan bahwa sensor jarak sudah berfungsi dengan baik untuk digunakan sebagai pengukur ketinggian air dan ketersediaan pakan ikan.

\section{E. Pengujian Modul RTC (Real Time Clock) DS1307}

Pada sistem pemberi pakan otomatis digunakan sebuah modul RTC tipe DS1307. Dimana modul RTC digunakan sebagai pewaktu untuk menghitung waktu dari detik hingga tahun. Waktu pada RTC akan diprogram sesuai dengan waktu pemberian pakan pada ikan koi yakni pada pukul 7 pagi, 12 siang dan 5 sore. Hasil pengujian modul RTC DS1307 ditunjukkan pada tabel 4.

TABEL 4

PENGUJIAN MODUL RTC DS1307

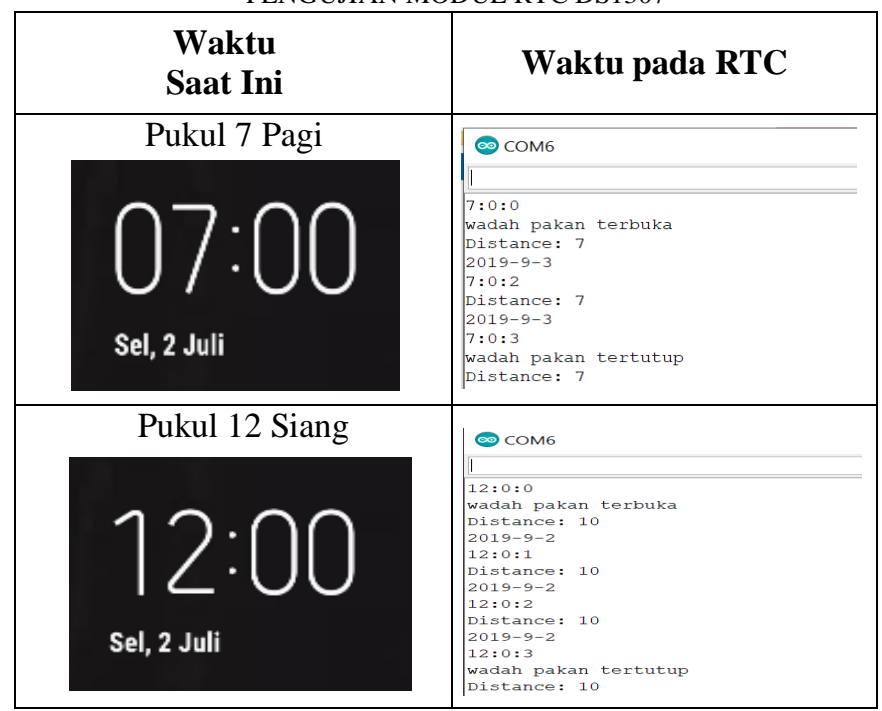




\begin{tabular}{|c|c|}
\hline Pukul 5 Sore & (ब сом6 \\
\hline 77 & 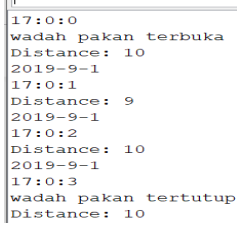 \\
\hline
\end{tabular}

Berdasarkan hasil pengujian yang telah dilakukan, jam dinding dan modul RTC DS1307 menunjukkan waktu yang sama dan modul RTC mengirimkan input waktu tersebut menuju mikrokontroler untuk kemudian menggerakkan tuas pakan ikan. Dengan demikian, dapat dikatakan bahwa modul RTC sudah berfungsi dengan baik untuk digunakan sebagai pewaktu pemberian pakan ikan.

\section{F. Pengujian Servo MG996R}

Pada sistem pemberi pakan otomatis digunakan sebuah motor servo tipe MG996R. Motor servo disini dignakan untuk menggerakkan tuas pakan ikan apabila RTC sudah menunjukkan waktu pemberian pakan ikan. Hasil pengujian motor servo MG996R dapat dilihat pada tabel 5.

TABEL 5

PENGUJIAN SERVO MG996R

\begin{tabular}{|c|c|}
\hline Waktu Saat Ini & $\begin{array}{c}\text { Keadaan Tuas } \\
\text { Pakan Ikan }\end{array}$ \\
\hline Pukul 12:00:00 & Terbuka \\
\hline $12.00: 00$ & \\
\hline Pukul 12:00:03 & \\
\hline $12: 00: 03$ & Tertutup \\
\hline june 2019 & \\
\hline
\end{tabular}

Pengujian dilakukan pada pukul 12 siang, dimana pada waktu tersebut adalah waktu yang di-setting pada modul RTC (Real Time Clock) untuk sistem memberikan pakan pada ikan. Waktu yang di-setting pada modul RTC untuk sistem memberikan pakan ikan adalah pada pukul 7 pagi, 12 siang dan 5 sore. Apabila sistem membaca waktu yang telah disetting tersebut, maka sistem akan menggerakkan motor servo yang digunakan sebagai tuas wadah pakan ikan dengan sudut $90^{\circ}$ sehingga wadah pakan terbuka dan menyebabkan pakan ikan jatuh menuju kolam. Kemudian, setelah 3 detik sistem akan menggerakkan motor servo kembali ke sudut $0^{\circ}$ sehingga wadah pakan ikan tertutup. Selang waktu terbuka dan tertutupnya tuas pakan ikan diberi jeda selama 3 detik dikarenakan dalam rentang waktu tersebut, pakan ikan yang jatuh ke kolam sudah banyak (waktu delay atau jeda pergerakkan motor servo membuka dan menutup ini dapat disetting dan desesuaikan dengan keperluan jumlah pemberian pakan di masing-masing kolam). Pada pengujian yang telah dilakukan, sistem sudah bekerja dengan sebagaimana mestinya sehingga dapat digunakan sebagai pemberi pakan ikan otomatis.

\section{G. Pengujian Modul Relay dan Pompa}

Pengurasan dan pengisian air kolam dilakukan dengan menggunakan pompa AC. Untuk mengaktifkan dan menonaktifkan pompa berdasarkan kondisi kolam digunakan modul relay pada masing-masing pompa yaitu pompa drainase (penguras air) dan pompa distribusi (penyalur air). Sistem relay yang digunakan pada penelitian ini adalah Normally Open yaitu pada keadaan normal berupa rangkaian terbuka dengan pin COM dan baru terhubung dengan pin COM saat relay aktif. Hasil pengujian pada masing-masing modul relay dan pompa dapat dilihat pada tabel 6 dan 7.

TABEL 6

PENGUJIAN MODUL RELAY DAN POMPA DRAINASE

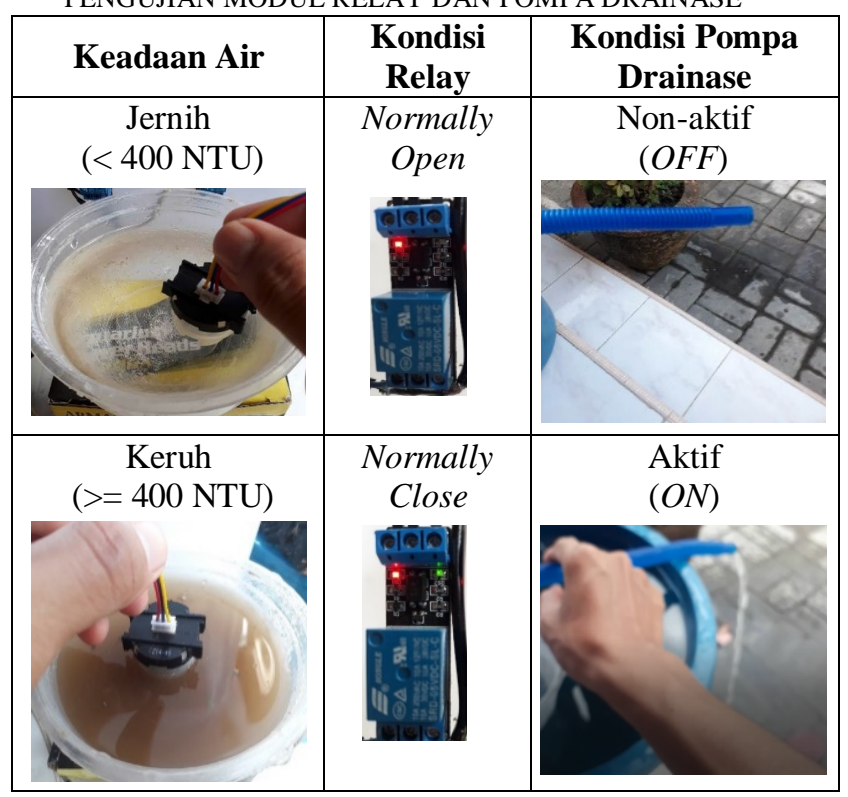

TABEL 7

PENGUJIAN MODUL RELAY DAN POMPA DISTRIBUSI

\begin{tabular}{|c|c|c|}
\hline Ketinggian Air & $\begin{array}{c}\text { Kondisi } \\
\text { Relay }\end{array}$ & $\begin{array}{c}\text { Kondisi Pompa } \\
\text { Distribusi }\end{array}$ \\
\hline
\end{tabular}




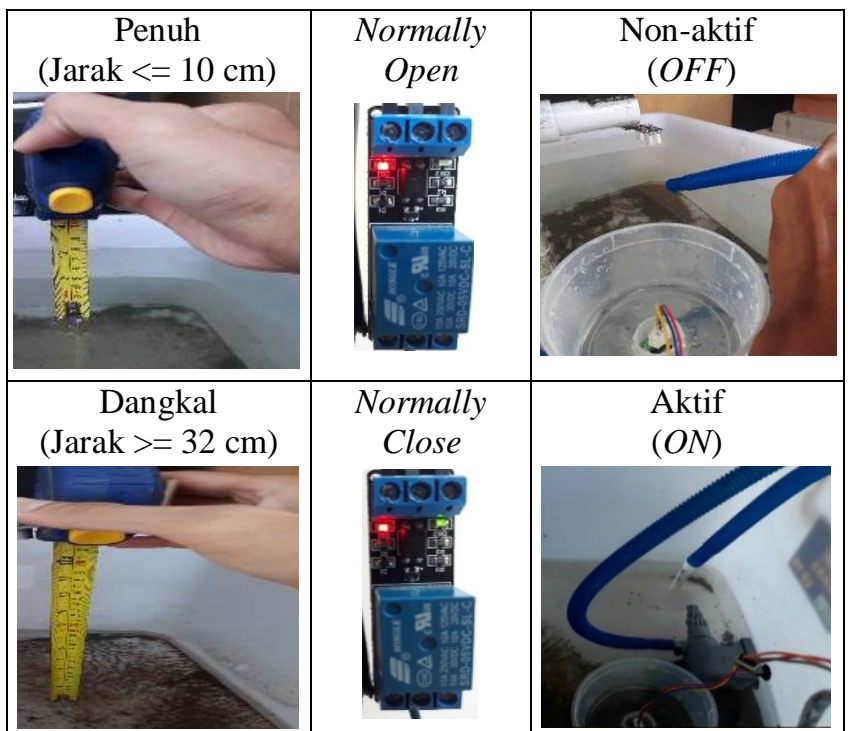

Berdasarkan pengujian yang telah dilakukan, modul relay sudah dapat mengontrol (mengaktifkan dan menon-aktifkan) pompa drainase sesuai dengan keadaan air kolam dan dapat mengontrol (mengaktifkan dan menon-aktifkan) pompa distribusi sesuai dengan ketinggian air kolam. Sehingga dapat dikatakan bahwa modul relay sudah berfungsi dengan baik.

\section{H. Pengujian Pengiriman Data Menuju Aplikasi Blynk}

Data pada sistem monitoring tingkat kekeruhan dan pemberi pakan otomatis akan dikirimkan menuju aplikasi Blynk dengan tujuan sistem dapat dimonitor dengan aplikasi dari jarak yang jauh. Untuk menggunakan aplikasi Blynk, pengguna hanya perlu men-setting widget yang akan digunakan. Setelah aplikasi selesai dibuat dan perangkat diberi program, maka perlu dilakukan pengujian pada aplikasi untuk mengetahui kehandalan aplikasi itu sendiri. Adapun beberapa hasil pengujian pengiriman data menuju aplikasi Blynk dan Email ditunjukkan pada gambar 17, 18 dan 19.

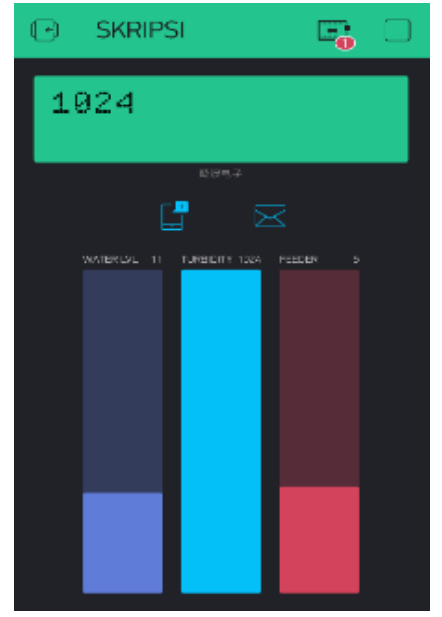

Gambar 17 : Hasil Pengujian Aplikasi Blynk untuk Mengukur Ketinggian Air, Kekeruhan Air dan Ketersediaan Pakan.

I Gede Hery Putrawan: Sistem Monitoring Tingkat Kekeruhan...

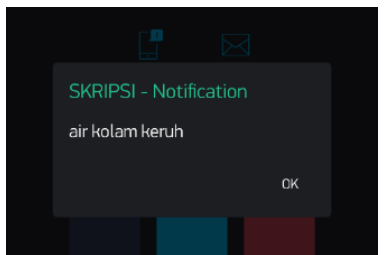

(a)

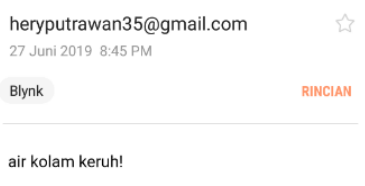

(b)
Gambar 18 : Hasil Pengujian Notifikasi pada Aplikasi saat Air Keruh (a) Notifikasi pada Aplikasi Blynk dan (b) Notifikasi pada E-mail

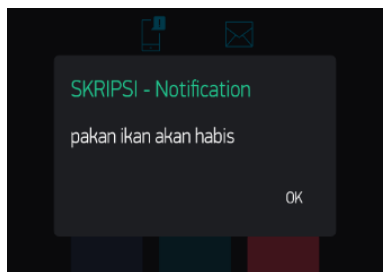

(a)

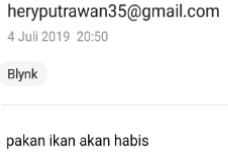

(b)
Gambar 19 : Hasil Pengujian Notifikasi pada Aplikasi saat Ketersediaan Pakan akan Habis (a) Notifikasi pada Aplikasi Blynk dan (b) Notifikasi pada E-mail

Berdasarkan hasil pengujian yang telah dilakukan, aplikasi yang dibuat sudah bekerja sesuai dengan fungsinya sebagai penampil data pada masing-masing sistem yakni sistem monitoring tingkat kekeruhan air dan sistem pemberi pakan ikan otomatis. Sehingga dapat dikatakan bahwa aplikasi sudah dapat digunakan dengan baik.

\section{KESIMPULAN}

Adapun kesimpulan yang didapat dari penelitian ini adalah sebagai berikut:

1. Prototipe sistem dirancang dengan menggunakan mikrokontroler Node-MCU, sensor kekeruhan TSD-10, sensor jarak HC-SR-04, RTC DS-1307, Motor Servo MG996R, Modul Relay dan Pompa serta Software Pemrograman Arduino IDE.

2. Prototipe sistem ini dapat memonitoring tingkat kekeruhan air kolam budidaya ikan koi serta secara otomatis melakukan pengurasan air kolam apabila air kolam sudah mencapai tingkat kekeruhan 400 NTU dan mengisi kolam kembali dengan air bersih. Namun pada sistem ini, pembacaan nilai sensor masih belum sepenuhnya stabil karena dipengaruhi cahaya disekitar. Hasil pembacaan nilai sensor dapat ditampilkan pada aplikasi Blynk pemilik kolam.

3. Prototipe sistem ini dapat memberikan pakan ikan secara otomatis sesuai dengan program yang diberikan pada mikrokontroler yakni tiga kali sehari pada pukul 7 pagi, 12 siang dan 5 sore. Apabila sudah waktunya pemberian pakan, maka sistem akan menggerakkan motor servo untuk membuka tuas wadah pakan ikan selama 3 detik kemudian menutup kembali. Kemudian, ketersediaan pakan ikan dapat dipantau melalui aplikasi Blynk pemilik kolam.

p-ISSN:1693 - 2951; e-ISSN: 2503-2372 


\section{REFERENSI}

[1] Faisal, Muhammad. 2019. Perancangan Sistem Monitoring Tingkat Kekeruhan Air Secara Realtime Menggunakan Sensor TSD-10. Jurnal Ilmu Fisika,Vol. $\quad 8, \quad$ No. $1, \quad 9-15$. http://jif.fmipa.unand.ac.id/index.php/jif/article/view/122.

[2] Eka Putra, Mustawan., 2017. Monitoring Penggunaan Daya Listrik sebagai Implementasi Internet of Things Bebasis Wireless Sensor Network. Majalah Ilmiah Teknologi Elektro, Vol. 16, No. 03, 50-55. https://ojs.unud.ac.id/index.php/JTE/article/view/ID28347/22029.

[3] Anggraeni, Mitha. 2016. Ikan Koi adalah Ikan yang Termasuk Ikan Mas. (https://prezi.com/k82fclcl9fro/ikan-koi-adalah-sejenis-ikan-yangtermasuk-ikan-mas-cyprinu/

[4] Sakti, Zein. 2016. Jenis-jenis Kolam Budidaya Ikan dan Desainnya. https://www.awalilmu.com/2016/02/jenis-jenis-kolam-budidaya-ikandan-desainnya.html.

[5] Cholik, F., Artati dan Arifudin, R. 1986. Pengelolaan Kualitas Air Kolam. INFIS Manual seri nomor 26. Dirjen Perikanan. Jakarta. 52 hal.

[6] International Standar Organization, 1999. Water Quality-Determination Of Turbidity. ISO 7027, Geneva, Switzerland.

[7] Payara, Marlex. 2014. Rancang Bangun Pengendalian Kualitas Air pada Sistem Monitoring Kualitas Kolam Ikan. http://library.usd.ac.id/Data\%20PDF/F.\%20Sains\%20dan\%20Teknologi /Teknik\%20Elektro/105114025 full.pdf.

[8] Wicaksono, Mochamad Fajar. 2017. Implementasi Modul WiFi NodeMCU ESP8166 untuk Smart Home. Jurnal Teknik Komputer

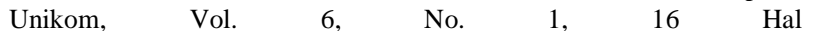
https://search.unikom.ac.id/index.php/komputika/article/view/339.

[9] Bondan. 2019. Turbidity Meter disebut juga Alat Ukur Kekeruhan Air. (https://indo-digital.com/turbidity-meter-disebut-juga-alat-ukurkekeruhan-air.html.

[10] Namirudin, Muhammad. 2017. Rancang Bangun Pemandu Tuna Netra Menggunakan Sensor Ultrasonik Berbasis Mikrokontroler. Majalah Ilmiah Teknologi Elektro, Vol. 16, No. 3, 27-32. https://ojs.unud.ac.id/index.php/JTE/article/view/ID27239/22023.

[11] Utama, Raka. 2018. Rancang Bangun Alat Otomatisasi Mantram Puja Trisandya Menggunakan Mikrokontroler ATMega328. Majalah Ilmiah Teknologi Elektro, Vol. 17, No. 1, 80-85. https://ojs.unud.ac.id/index.php/JTE/article/view/30723/24135.

[12] Abhisena, I. G., dkk. 2016. Internet of Things D.I.Y Project Smart Pet Feeder Solusi Pemberi Makan Hewan Otomatis. Bali: Program Studi Teknik Teknologi Informasi Universitas Udayana.

[13] Kho, Dickson. 2019. Pengertian Relay dan Fungsinya. https://teknikelektronika.com/pengertian-relay-fungsi-relay/.

[14] Sinaryuda. 2017. Mengenal Arduino IDE dan Arduino Sketch. https://www.sinaryuda.web.id/microcontroller/mengenal-aplikasiarduino-ide-dan-arduino-sketch.html.

[15] Faudin, Agus. 2017. Mengenal Aplikasi Blynk untuk Fungsi IoT. https://www.nyebarilmu.com/mengenal-aplikasi-blynk-untuk-fungsiiot/ 